\begin{tabular}{cc}
\hline & International Journal of Engineering \& Technology, $7(2.1)(2018)$ 54-58 \\
SPC & International Journal of Engineering \& Technology \\
\hline
\end{tabular}

\title{
Utilization of Sustainable Materials to Enhance Geotechnical Characteristics of Soils
}

\author{
Rama Subba Rao, G.V." \\ Associate Professor, Department of Civil Engineering, V.R. Siddhartha Engineering College, \\ Vijayawada, Andhra Pradesh, India \\ *Corresponding author E-mail: gvramasubbarao@gmail.com
}

\begin{abstract}
Geotechnical engineering can noticeably affect the sustainability of infrastructure development because of its beginning place in the construction practice. Utilization of waste materials for enhancing properties of the soil is a wise choice and is also one step towards accomplishing sustainable development. Application of by-products (viz., flay ash and rice husk ash) which could be defined as "sustainable materials", find special place in the modern-day soil stabilization and modification exercise. The preset paper aims at enhancing properties of expansive soil with inclusion of industrial by-products namely Rice Husk ash and Fly Ash. Further the present paper focuses on improving geotechnical characteristics of fine sand upon reinforcing with ground shredded rubber tire. Fine sand has a low angle of internal friction and which in turn has low shear strength. Reuse of waste materials is one area of research which attempts to makes geotechnical engineering practice sustainable.
\end{abstract}

Keywords: Sustainable, Rice Husk Ash, Fly Ash, Ground Shredded Rubber Tire.

\section{Introduction}

Soil is the basic construction material. It supports the substructure of any structure and it is the subgrade which supports the subbase/base in the pavement. The existing soil at a particular location may not be suitable for the construction due to poor bearing capacity and higher compressibility or even sometimes excessive swelling in case of expansive soils. There is a need to concentrate on improving properties of soils using cost-effective practices like treating with industrial by-products/wastes which may have cementitious value. Consulting Geotechnical Engineers use soil as a construction material in various applications such as for earth dams, road and railway embankments, filling of low-lying areas, and filling behind retaining structures. Several million cubic metres of earth works are executed each year in India alone. Geotechnical engineering has a crucial role in shaping and achieving the sustainability credentials of a project. Sustainable materials are those products that provide environmental, social and economical benefits while protecting public health and environment over their whole life cycle, from the extraction of raw materials until the disposal.

Geotechnical engineering is one of the key contributing fields to sustainable development. This paper presents research studies performed on utilization of waste materials in geotechnical engineering related to overall sustainable development. In this study, industrial by-products like RHA and FA are used to improve geotechnical properties of a soil. Further studies were also carried to determine the geotechnical properties of rubber-fine sand mixtures in order to be used as a backfill material for retaining walls. Ground shredded Rubber Tire (GSRT) was blended to fine sand to assess the suitability of GSRT blended fine sand as a backfill material. Unit weight, cohesion, friction angle, permeability are the major characteristics for the selection of material used as a backfill material.

\section{Utilisation of Industrial By-Products (Rice Husk Ash and Fly Ash) In Improving Ex- pansive Soils}

Expansive soils are extremely problematic owing to swell on imbibition of water and shrink on evaporation thereof. Alternate swell and shrinkage leads to distress to the foundations of structures laid on such soils. The problem is aggraved further in case of lightly loaded structures those cannot counteract the upward thrust Rice is the basic source of food for billions of populace around the globe. Rice husk is the shell formed during dehusking of paddy. India is the second largest producer of rice. RHA is obtained from the burning of rice husk which is the byproduct of rice milling. It was estimated that $1000 \mathrm{~kg}$ of rice grain produced $200 \mathrm{~kg}$ of rice husk, on burning the rice husk about $20 \%$ or $40 \mathrm{~kg}$ would become RHA. RHA has the potential to be used as a substitute for silica fumes or micro silica at a much lower cost. Well-burnt RHA passed through $425 \mu$ was used in this investigation for convenient mixing with clay and compaction. Several investigators studied the influence of RHA in soil stabilisation [1] [2]. Fly ash is waste material producing due to burning of coal for thermal power industries. It is a hazardous material causing environmental degradation. FA is the finely divided mineral residue resulting from the combustion of ground or powdered coal in electric generating plant. Flay Ash can be either Class C or Class F [3]. From pozzolanic point of view the Indian coal ashes fall in the category of 
class F. In view of their good physical properties, they can be used beneficially in most of the geotechnical applications [4]. In current years, the engineering community feels that massive consumption of ash is likely through geotechnical applications. Some of researchers studied the effect of RHA-FA on soil properties [5] and also effect of RHA-lime on characteristics of soil [6] [7]. A study carried by [8] presented results of which is aimed at evaluating the durability and removal of lime from lime-stabilized Class-F fly ash. Leaching and hydraulic conductivity characteristics of the compacted FA mixed with various percentage of lime (4-10\%) were investigated. The results of the study show that the hydraulic conductivity decreases with increase in lime content. Curing period was found to further decrease the hydraulic conductivity.

Utilisation of industrial by-products such as RHA and FA for soil improvement is a sustainable and cost-effective technique. A study carried out to use industrial by-products namely RHA and FA to improve characteristics of an expansive soil. An Expansive soil is replaced with RHA in $2 \%, 4 \%$ and $6 \%$ to dry weight of soil. It is observed that soil replaced with $4 \%$ RHA is the optimum for the soil used in this study from geotechnical point of view. To know the influence of FA, soil is further replaced with 4\% FA along with $4 \%$ RHA. It is found that results of soil replacement by both RHA and FA proved to be soil modification and not the improvement. Hence a cost effective accelerator like lime is used for further replacing the above Soil-4\%RHA-4\%FA mix. The optimum lime content is found to be $4 \%$. Geotechnical properties studied in this investigation includes Index properties like Liquid Limit, Plastic Limit and Differential Free Swell Index, and Engineering properties like Compaction and Strength characteristics of soil with and without replacement of various proportions of RHA. It is observed that soil replaced with $4 \%$ RHA is the optimum RHA (ORHA) for the soil used in this study from view point of plasticity, swelling and strength. In order to understand the effect of FA, soil is replaced with 4\% FA together with 4\%RHA. It is found that geotechnical properties of soil replacement by both RHA and FA proved to be modifying properties of soil not for the enhancement. Hence a low cost accelerator like lime (L) is used for further replacing the above soil-4\%RHA-4\%FA mix. To find OLC, Eades and Grim pH method [9] is adopted and OLC is $4 \%$ for the above mix. The OLC is proved to be $4 \%$ from geotechnical properties for soil-4\%RHA-4\%FA mix.

\subsection{Materials Used}

Soil was collected from Enikepadu, Vijayawada's rural area. The properties of the soil are evaluated and presented in Table-1.The chemical properties of RHA are mentioned in Table-2 as per IPSIT [10]. From the Table-2, it is clear that silica is the major constituent of the RHA. The RHA used in this investigation obtained from nearby industry. The $\mathrm{pH}$ value of the RHA used in this work is 10.96. Fly ash has been obtained from the electrostatic precipitator hoppers of Vijayawada Thermal Power Station (VTPS), Ibrahimpatnam. The Fly ash used in this investigation comes under category of Class-F. The Specific Gravity of FA is 2.10, fraction finer than $75 \mu \mathrm{m}$ is $79.93 \%$ rest being coarser than $75 \mu \mathrm{m}$ but finer than $425 \mu \mathrm{m}$, Maximum Dry Unit weight is $13.63 \mathrm{kN} / \mathrm{m}^{3}$ and Optimum Moisture Content is $21.4 \%$. The $\mathrm{pH}$ value of the FA is 9.64 Commercially available hydrated lime is used in this investigation. The $\mathrm{pH}$ value of lime used in this study is 12.80 . Table- 3 shows the $\mathrm{pH}$ test results of soil-4\%RHA- $4 \% \mathrm{FA}$ with $2 \%, 4 \%, 6 \%$ and $8 \%$ lime. The $O L C$ for the soil-4\%RHA-4\%FA mix obtained from Eades and Grim $\mathrm{pH}$ method. At $4 \% \mathrm{~L}, \mathrm{pH}$ value is nearly and above 12.4 , therefore $4 \% \mathrm{~L}$ is the OLC for soil-4\%RHA-4\%FA mix.
Table 1: Properties of Soil

\begin{tabular}{|l|l|}
\hline Property & Value \\
\hline Specific gravity & 2.69 \\
\hline Gravel & $0 \%$ \\
\hline Sand & $14.17 \%$ \\
\hline Fines & $85.83 \%$ \\
\hline Liquid limit & $77 \%$ \\
\hline Plastic limit & $40 \%$ \\
\hline Plasticity Index & $7 \%$ \\
\hline Classification of Soil (USCS) & MH \\
\hline Differential Free Swell Index (DFSI) & $70 \%$ \\
\hline Degree of Expansivity & Very High \\
\hline Maximum Dry Density (MDD) & $14.98 \mathrm{kN} / \mathrm{m}^{3}$ \\
\hline Optimum Moisture Content (OMC) & $26.1 \%$ \\
\hline pH value & 8.6 \\
\hline
\end{tabular}

Table-2: Chemical Composition of Rice Husk Ash

\begin{tabular}{|l|l|}
\hline Constituent & Percentage \\
\hline Silica $\left(\mathrm{SiO}_{2}\right)$ & 91.1 \\
\hline Alumina $\left(\mathrm{Al}_{2} \mathrm{O}_{3}\right)$ & 0.4 \\
\hline Calcium Oxide $(\mathrm{CaO})$ & 0.4 \\
\hline Ferric Oxide $\left(\mathrm{Fe}_{2} \mathrm{O}_{3}\right)$ & 0.4 \\
\hline Sodium $\left(\mathrm{Na}_{2} \mathrm{O}\right)$ & 0.1 \\
\hline Sulphur $\left(\mathrm{Na}_{2} \mathrm{O}\right)$ & 0.1 \\
\hline Magnesium Oxide $(\mathrm{MgO})$ & 0.5 \\
\hline Potassium Oxide $(\mathrm{KaO})$ & 2.2 \\
\hline Loss on Ignition & 4.8 \\
\hline
\end{tabular}

Table-3: pH Test Results

\begin{tabular}{|l|l|}
\hline Material/Mix & $\mathrm{pH}$ value \\
\hline Soil-4\%RHA-4\%FA-2\%L & 11.63 \\
\hline Soil-4\%RHA-4\%FA-4\%L & 12.42 \\
\hline Soil-4\%RHA-4\%FA-6\%L & 12.68 \\
\hline Soil-4\%RHA-4\%FA-8\%L & 12.70 \\
\hline
\end{tabular}

\subsection{Influence of RHA \& FA on Index Properties}

Liquid Limit (LL), Plastic Limit (PL) and Differential Free Swell Index (DFSI) tests are conducted on soil with and without replacements. Plasticity Index (PI) is calculated from the deduction of PL from LL. Index properties like LL, PL and DFSI for soil replaced with $2 \%, 4 \%, 6 \%, 8 \%, 10 \%$ and $12 \%$ RHA to dry weight of soil are presented in Table- 4 . The LL decreased from $76.89 \%$ to $66.80 \%$ with increase in RHA content from $0 \%$ to $4 \%$ respectively. This can be considered to be as a consequence of the substitute of the soil fines by RHA. The later which has less affinity for water, caused the drop in LL. As the RHA was further increased from $4 \%$ to $12 \%$, the LL increased from $66.80 \%$ to $79.14 \%$ respectively. At this stage the RHA quantity increased to an extent that more water will be required to turn the soil-RHA mix to fluid. The variation of PL is similar to that of the LL with increase in \% RHA. The reasons for the variation of LL with RHA content are also similar to that of the variation of PL with RHA content. PI decreased from $36.45 \%$ to $22.43 \%$ with increase in RHA content from $0 \%$ to $4 \%$. This scenario may be attributed to the replacement of the finer soil particles by the RHA with consequent reduction in the clay content and plasticity index. LL, PI and DFSI is decreased to $40.29 \%, 9.92 \%$ and $40 \%$ for soil replaced with $4 \%$ RHA-4\%FA. Soil has DFSI of $70 \%$ and it is decreased to $50 \%$, $40 \%$ with $4 \%$ RHA and $4 \%$ RHA- $4 \%$ FA replacement of soil, respectively. The decrease may be due to increase in coarser particles in soil-RHA-FA mix. Lime in proportions of $2 \%, 4 \%$ and $6 \%$ also replaced the soil-4\%RHA-4\%FA mix for the purpose of higher cementation and decontamination. DFSI values for various proportions of soil replacements are presented in Table-4. It is observed that 4\%RHA is optimum with respect to DFSI. Finally, 4\%RHA replacement is the ORHA in view of index properties. 
Soil replaced with $4 \% \mathrm{RHA}+4 \% \mathrm{FA}+4 \% \mathrm{~L}$ has the DFSI of $30 \%$. Hence, $4 \% \mathrm{~L}$ is the $O L C$ for soil- $4 \% \mathrm{RHA}+4 \% \mathrm{FA}$ mix in view of index properties.

Table-4: Index Properties of Soil with Replacements

\begin{tabular}{|l|l|l|l|l|}
\hline Soil replaced with & $\begin{array}{l}\text { LL } \\
(\%)\end{array}$ & $\begin{array}{l}\text { PL } \\
(\%)\end{array}$ & $\begin{array}{l}\text { PI } \\
(\%)\end{array}$ & $\begin{array}{l}\text { DFSI } \\
(\%)\end{array}$ \\
\hline $2 \%$ RHA & 77.51 & 39.16 & 38.35 & $60 \%$ \\
\hline $4 \%$ RHA & 66.8 & 44.36 & 22.44 & $50 \%$ \\
\hline $6 \%$ RHA & 79.14 & 45.66 & 33.48 & $55 \%$ \\
\hline $8 \%$ RHA & 78.38 & 44.05 & 34.33 & $60 \%$ \\
\hline $10 \%$ RHA & 79.14 & 45.66 & 33.48 & $60 \%$ \\
\hline $12 \%$ RHA & 79.86 & 47.82 & 32.04 & $65 \%$ \\
\hline $4 \%$ RHA+4\%FA & 40.29 & 30.37 & 9.92 & $40 \%$ \\
\hline $4 \%$ RHA+4\%FA+2\%L & 63.11 & 39.39 & 23.72 & $40 \%$ \\
\hline 4\%RHA+4\%FA+4\%L & 64.75 & 38.02 & 26.73 & $30 \%$ \\
\hline 4\%RHA+4\%FA+6\%L & 56.73 & 37.62 & 19.11 & $40 \%$ \\
\hline
\end{tabular}

\subsection{Influence of RHA \& FA on Engineering Character-} istics

Standard Compaction tests were conducted on soil with and without replacements. Compaction characteristics namely Maximum Dry Density (MDD) and Optimum Moisture Content (OMC) are presented in Table-5. MDD is increased up to 4\%RHA and beyond which it decreases while the OMC decreased up to 4\%RHA and beyond which it increases. MDD is increased and OMC decreased with 4\%RHA-4\%FA. MDD and OMC of soil replaced with $4 \%$ RHA- $4 \%$ FA-2\%L are $1.710 \mathrm{Mg} / \mathrm{m}^{3}$ and $23.3 \%$. MDD decreases for soil replaced with $4 \%$ RHA- $4 \% \mathrm{FA}-4 \% \mathrm{~L}$ and 4\%RHA-4\%FA-6\%L. OMC increases for soil replaced with 4\%RHA-4\%FA-4\%L and again decreases for soil replaced with 4\%RHA-4\%FA-6\%L. Unconfined compression tests are conducted on soil specimens with and without replacements for 0 and 7 days curing. The specimens are compacted to their respective MDD's and OMC's of the mixes. Unconfined compressive strength (UCS) and failure strains are summarized in Table-6. There is an increase in UCS value from 70 to $260 \mathrm{kPa}$ for uncured specimens and 70 to $560 \mathrm{kPa}$ for 7 -day cured specimens replaced with $0 \%$ to $6 \%$ RHA. Curing increases the strength due to pozzolanic reaction. Percentage increase in UCS is higher for 4\%RHA. Therefore, $4 \%$ RHA is the ORHA with respect to strength. The decrease in rate of strength increase after 4\% RHA could be attributed to the excess RHA that could not be utilized for the cementation reaction. UCS for 0-day and 7-days cured soil replaced with $4 \%$ RHA- $4 \%$ FA increases to $260 \mathrm{kPa}$ and $566 \mathrm{kPa}$ respectively. UCS for 7-days cured soil replaced with 4\%RHA$4 \% \mathrm{FA}-6 \% \mathrm{~L}$ increases to $1204 \mathrm{kPa}$ i.e. is about 1600 times as compared to untreated soil strength. The percentage increase in strength is higher for 7-days cured soil replaced with 4\%RHA$4 \% \mathrm{FA}-4 \% \mathrm{~L}$ mix. Hence, $4 \% \mathrm{~L}$ is the $O L C$ for soil-4\%RHA-4\%FA mix in view of strength. Chemical reactions that occur when soil treated with RHA, FA and L includes cation exchange, carbonation and pozzolanic reactions leading to formation of CalciumSilicate-Hydrate (C-S-H) gel. This new geometrical can be used as sub base course for pavements [11]. Transport Research Laboratory, UK recommended UCS value of $750-1500 \mathrm{kPa}$ for sub-base course of pavements.

Table-5: Compaction Characteristics of Soil with Replacements

\begin{tabular}{|l|l|l|}
\hline Soil replaced with & \multicolumn{2}{|l|}{ Compaction Characteristics } \\
\cline { 2 - 3 } & $\begin{array}{l}\text { Maximum } \\
\text { Dry Density } \\
\text { (in kN/m }{ }^{3} \text { ) }\end{array}$ & $\begin{array}{l}\text { Optimum } \\
\text { Moisture } \\
\text { Content } \\
(\%)\end{array}$ \\
\hline $4 \%$ RHA & 15.32 & 22.5 \\
\hline $6 \%$ RHA & 14.99 & 27.0 \\
\hline $4 \%$ RHA+4\%FA & 16.60 & 13.8 \\
\hline $4 \%$ RHA+4\%FA+2\%L & 17.10 & 23.3 \\
\hline $4 \%$ RHA+4\%FA+4\% L & 17.03 & 25.3 \\
\hline $4 \%$ RHA+4\%FA+6\%L & 14.70 & 24.81 \\
\hline
\end{tabular}

Table-6: Unconfined Compressive Strength (UCS) of soil with replacements

\begin{tabular}{|l|l|l|}
\hline \multirow{2}{*}{ Soil replaced with } & \multicolumn{2}{|l|}{$\begin{array}{l}\text { UCS } \\
\text { (in kPa) }\end{array}$} \\
\cline { 2 - 3 } & 0-day curing & 7-days curing \\
\hline 0\% RHA & 70.00 & 70 \\
\hline $4 \%$ RHA & 129 & 210 \\
\hline $6 \%$ RHA & 169 & 240 \\
\hline 4\%RHA+4\%FA & 260 & 566 \\
\hline $4 \%$ RHA+4\%FA+2\%L & 141 & 484 \\
\hline 4\%RHA+4\%FA+4\%L & 122 & 899 \\
\hline 4\%RHA+4\%FA+6\%L & 174 & 1204 \\
\hline
\end{tabular}

\section{Utilisation of Ground Shredded Rubber Tire in Improving Sandy Soil}

Scrap tires are waste materials and recycling these materials is indispensible. The large numbers of tires are disposed of every year. A more productive, environmentally desirable use of these tires would be the construction of embankments and backfills with tire shreds or mixture of tire shreds and sand. Such fills are lighter than traditional soil fills. The use of scrap tires as construction materials in civil engineering applications is one of the most promising ways of recycling this troublesome waste material presented by [12]. Shredded scrap tires have been used as construction materials in civil engineering applications including retaining wall backfill, road embankments and subsurface drainage systems presented by [13]. The most important property is that tire shreds are lightweight. Tire shreds have various shapes and sizes typically varying between 50 and $300 \mathrm{~mm}$.

Table-7: Classification of tire pieces based on the size of shredded tire

\begin{tabular}{|l|l|}
\hline Classification & Size \\
\hline Ground rubber & $425 \mu \mathrm{m}-2 \mathrm{~mm}$ \\
\hline Granulated rubber & $425 \mu \mathrm{m}-12 \mathrm{~mm}$ \\
\hline Tire chips & $12-50 \mathrm{~mm}$ \\
\hline Tire shreds & $50-305 \mathrm{~mm}$ \\
\hline Tire derived aggregate & $12-305 \mathrm{~mm}$ \\
\hline Rough shred & $\begin{array}{l}>50 \mathrm{~mm} \text { by } 50 \mathrm{~mm} \text { by } 50 \mathrm{~mm} \text { but } \\
\text { less than } 762 \mathrm{~mm} \text { by } 50 \mathrm{~mm} \text { by } \\
100 \mathrm{~mm}\end{array}$ \\
\hline
\end{tabular}

Fine sands are not chosen as backfill material owing to low shearing resistance and poor drainage. Several investigations were carried on various civil engineering applications of tire shreds. Fine sands are not preferred as backfill material due to low shearing resistance and poor drainage. Back fill is a material which is used to refill trenches and to fill some of the engineering structures such as highways, embankments, retaining structures etc., in the retaining structures backfill plays a major role to reduce active pressure on the retaining structure. Specific design requirement of backfill is need to use low density fill to reduce settlement. Rubberized portland cement concrete (rubcrete) mixture generally has a reduced compressive strength but it possesses a number of desirable properties, such as lower density, higher toughness, higher impact resistance, enhanced ductility, and more efficient sound and heat insulation compared to conventional concrete shown by [15]. Laboratory and field studies were conducted to investigate the performance of tire chips as a drainage medium in landfills. The leachate flow rates and total leachate volumes generated by the two field test cells are comparable indicating no retardation of leachate drainage due to use of tire chips instead of gravel as the leachate collection layer material. The steel belting is sometimes removed during processing of the tire shreds. The objective of this study was to determine the geotechnical properties of rubber-fine sand mixtures in order to be used as a backfill material for retaining walls. In the present study GSRT were blended to fine sand to assess the suitability of GSRT blended fine sand as a backfill material. Unit weight, cohesion, friction angle, permeability are the major characteristics for the selection of material used as a backfill 
material. For the evaluating these parameters the following tests were conducted: Unit Weight Test, Direct Shear Test, and Permeability Test. Tests on were conducted on fine sand added with GSRT of $1 \%, 2 \%$, and $3 \%$ of dry weight of fine sand. Tests were conducted in both loose and dense states.

\subsection{Materials Used}

The soil used here is sand. It has been collected from bank of River Krishna. The sand was sieved through $425 \mu$ IS sieve and retained on $75 \mu$ IS sieve to ensure the sand is in grain size range of fine sand. Discarded tires are collected from a cycle shop. Tires are so cleaned and shredded by removing strips of iron wires from the tires. After shredding the rubber tires, pieces were passed through $2 \mathrm{~mm}$ sieve and retained on $425 \mu$ sieve to meet the grain size requirement of Ground Shredded Rubber Tire (GSRT). GSRT used in present study are shown in Fig. 1.

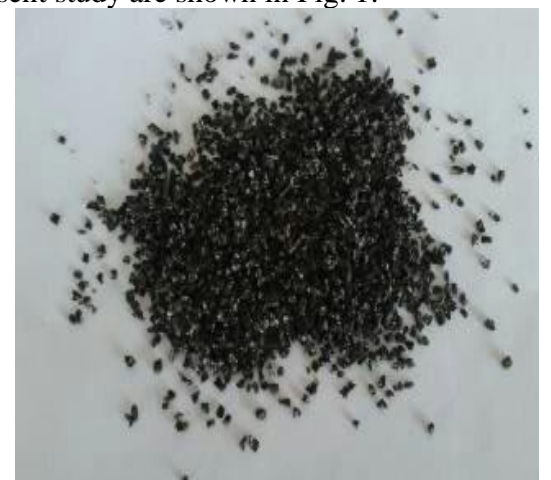

Fig. 1: Ground Shredded Rubber Tire (GSRT)

\subsection{Effect of GSRT on Dry Density of Fine Sand}

Density of fine sand added with and without addition of GSRT in loose and dense states. Values of dry unit weight of fine sand with addition of GSRT in loose and dense states were presented in Fig. 2. It was observed from the Fig. 2, addition of GSRT to fine sand decreases the dry unit weight. The decrease in dry unit weight was much pronounced up to $2 \%$ addition of GSRT to fine sand and thereafter the decrease is marginal. It can be note that the $2 \%$ is the Optimum Tire Content (OTC) with respect to Dry Unit Weight. The reduction of dry unit weight reduces the lateral earth pressure acting on retaining structures.

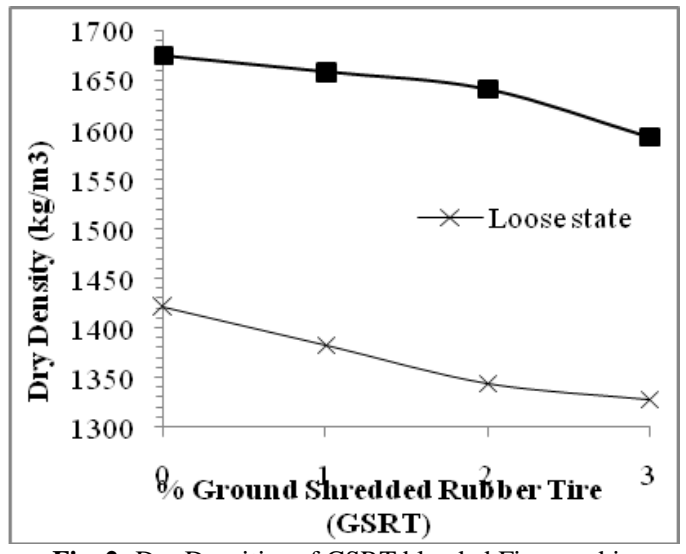

Fig. 2: Dry Densities of GSRT blended Fine sand in loose and Dense States

\subsection{Effect of GSRT on Engineering Properties of Fine Sand}

Shear strength parameters namely cohesion and angle of internal friction $(\phi)$ of the granular soil helps in estimating the earth pressures behind the retaining walls. The purpose of conducting direct shear tests is to determine shear strength parameters of blended soil. $\phi$ values of fine sand added with GSRT were presented in Fig. 3. It was observed from Fig. 3, addition of GSRT to fine sand enhances the angle of internal friction up to $2 \%$ addition of GSRT to fine sand for both dense and state. It can be noticed that the $2 \%$ is the Optimum Tire Content (OTC) with respect to Dry Unit Weight. The increase in angle of internal friction reduces the lateral earth pressure acting on retaining structures. Variable head permeability was conducted to determine the Coefficient of Permeability $(\mathrm{k})$ of fine sand blended with different proportions of GSRT $(0 \%, 1 \%, 2 \%$ and $3 \%$ of dry weight of sand). Permeability Tests were conducted in both loose and dense states. Coefficient of permeability values of fine sand added with GSRT were presented in Fig. 4. From Fig. 4, it is observed that, with the addition of GSRT, the coefficient of permeability increases for both loose and dense states.

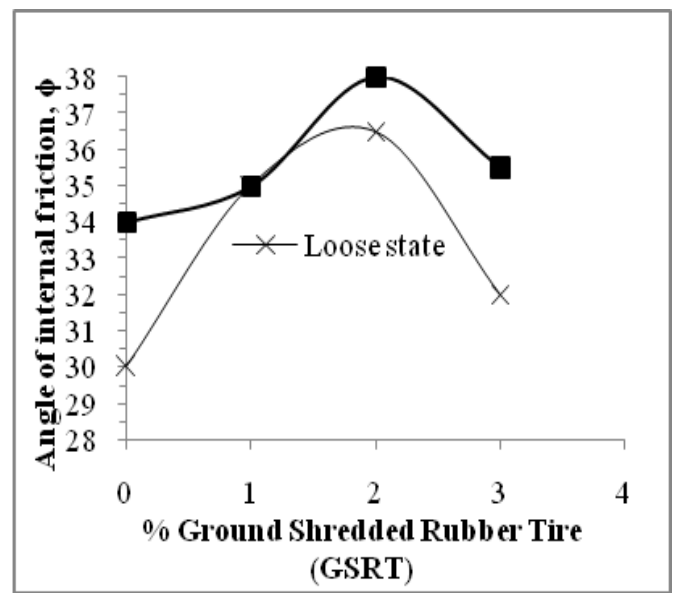

Fig. 3: $\phi$ values of GSRT blended fine sand in loose and Dense States

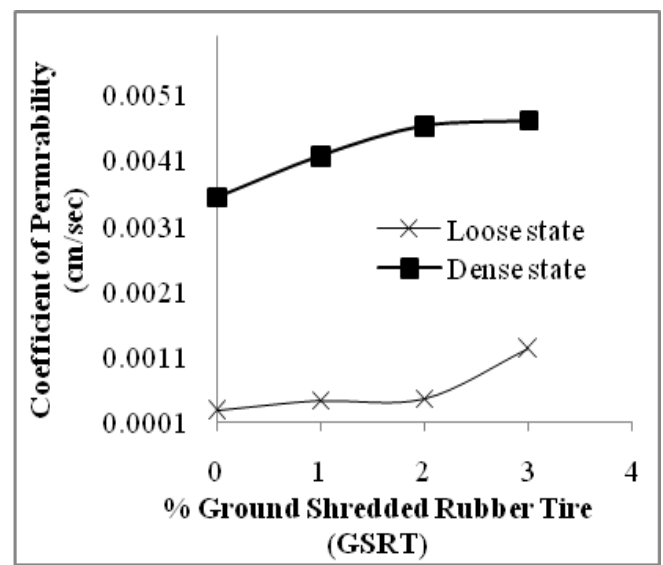

Fig. 4: Coefficient of Permeability (k) of GSRT blended fine sand in Loose and Dense States

\subsection{Computing Active Earth Pressure}

Active earth pressure is due to the force exerted by the soil on the back of the retaining structure. It plays an important role in the stability of retaining wall. Fine sand cannot be used as a back fill material but mixture of fine sand with GSRT can be used as back fill because of unit weight of fine sand is reduced by adding GSRT. This enables engineer to select a material having better qualities and relatively cheaper material. Rankine's theory is used for computing active force for any given height of wall. The values of active force exerted by GSRT blended fine sand on any given height of retaining wall for loose and dense states. The percentage reduction in active force was calculated for both loose and dense sates and it was observed that the \% reduction in active force was much pronounced with $2 \%$ addition of GSRT to fine sand. 


\section{Conclusions}

From the present study the following conclusions can be drawn:

1. From view point of Index properties, replacement of soil with 4\% Rice Husk Ash (RHA) is the optimum RHA content. Unconfined Compressive Strength (UCS) is increased with RHA content. The increase in strength is higher when 4\% RHA is replaced as compared to 6\%RHA. Therefore 4\% RHA is the optimum RHA content.

2. Curing further improved strength of RHA treated soil. In replacement of soil with 4\% Fly Ash (FA) together 4\%RHA, the UCS after 7-days curing is increased to 70\%. UCS of 7days cured soil sample replaced with 4\%RHA-4\%FA-6\%L mix is increased to $1620 \%$.

3. The percentage increase in strength is higher for 7-days cured soil replaced with $4 \%$ RHA- $4 \%$ FA- $4 \%$ L mix. Hence, $4 \% \mathrm{~L}$ is the Optimum Lime Content for soil-4\%RHA-4\%FA mix in view of strength. Soil replaced with 4\%RHA-4\%FA$4 \% \mathrm{~L}$ mix, improved the properties of soil. This new geomaterial can be used as sub base course for pavements. DFSI for this mix is $30 \%$. Hence, this mix can also used as a cushioning material under the expansive soil bed.

4. The addition of Ground Shredded Rubber Tire (GSRT) to fine sand decreases the dry density and increases the angle of internal friction in both loose and dense states. The Optimum Tire Content (OTC) is $2 \%$ with respect to Dry unit weight and shear strength.

5. With the addition of GSRT, coefficient of permeability (drainage characteristics) increases in both dense and loose states. There is a significant reduction in active earth pressure of about $27 \%$ in loose state and $17 \%$ in dense state for fine sand blended with $2 \%$ of GSRT. Usage of discarded rubber tire in geotechnical infrastructure is one viable option of achieving sustainable development.

\section{Acknowledgement}

Author is grateful to Dr. K. Mallikarjuna Rao, Professor, Department of Civil Engineering, SVU College of Engineering, Tirupati, Andhra Pradesh, India for his valuable guidance.

\section{References}

[1] Muntohar AS (2002), Utilization of uncontrolled burnt RHA in soil improvement, Dimensi Teknik Sipi, Vol. 4, No. 2, 100- 05.

[2] Okafor FO \& Okonkwo UN (2009), Effect of Rice Husk Ash on Some Geotechnical Properties of Lateritic Soil, Leonardo Electronic Journal of Practices and Technologies, Issue 15, JulyDecember, 67-74

[3] ASTM C618-03, Standard Specification for Coal Fly Ash and Raw or Calcined Natural Pozzolan for Use as a Mineral Admixture in Portland cement Concrete, American Society for Testing of Materials, Pennsylvania, USA, 2003.

[4] Sridharan A, Pandian NS \& Subramanya Prasad P (2001), Classification of Coal Ashes for Geotechnical Engineering Practice, Proceedings of International Conference on Civil Engineering, Indian Institute of Science, Bangalore, 738-745.

[5] Brooks RM (2009), Soil stabilization with fly ash and Rice husk ash, International Journal of Research and Reviews in Applied Sciences, Volume 1(3), 209-217.

[6] Muntohar AS \& Hantoro G (2000), Influence of Rice Husk Ash and Lime on Engineering Properties of a Clayey Subgrade, Electronic Journal of Geotechnical Engineering.

[7] Phani Kumar BR, Sharama S \& Vara Prasad Rao B (2008), Engineering Behavior of a Remolded Expansive Clay Blended with Lime, Calcium Chloride, and Rice-Husk Ash, Journal of Materials in Civil Engineering, ASCE, 509-515.

[8] Ghosh A \& Subbarao C (2007), Strength characteristics of class F fly ash modified with lime and gypsum, Journal of Geotechnical and Geoenvironmental Engineering, American Society of Civil Engineers, Vol. 133(7), 757-766.
[9] Eades JL \& Grim RE (1966), A quick test to determine lime requirement for lime stabilization, Highway Research Records, 139, 62-72.

[10] IPSIT, Precipitated Silica from Rice Husk Ash, Indian Institute of Science Precipitated Silica Technology, Combustion, Gasification \& Propulsion Laboratory (CGPL), Indian Institute of Science, Bangalore, India.

[11] ARMY TM 5-822-14, AIR FORCE AFJMAN 32-1019, Soil Stabilization for Pavements, Department of the Army, the Navy, and the Air force, October 1994

[12] Yang S, Lohnes RA \& Kjartanson BH (2002), Mechanical Properties of Shredded Tires, Geotechnical Testing Journal, Vol. 25, 44-52.

[13] Bosscher PJ, Edil TB \& Eldin N (1993), Construction and Performance of Shredded Waste Tire Test Embankment, Transportation Research Record, Vol. 1345, 44-52.

[14] ASTM D6270-08, Standard Practice for Use of Scrap tires in Civil Engineering Applications, American Society for Testing of Materials, 2008.

[15] Nehdi M \& Khan A (2001), Cementitious Composites Containing Recycled Tire Rubber: An Overview of Engineering Properties and Potential Applications, Cement, Concrete, and Aggregates, Vol. 23, 3-10. 